\title{
A Review of Affective Strategy and Social Strategy in Developing Students' Speaking Skills
}

\author{
Norfaeza Zakaria1, Harwati Hashim ${ }^{2 *}$, Melor Md. Yunus ${ }^{2}$ \\ ${ }^{1}$ SRA At-Takwa, Temerloh, Malaysia \\ ${ }^{2}$ Faculty of Education, Universiti Kebangsaan Malaysia, Bangi, Malaysia \\ Email: *harwati@ukm.edu.my
}

How to cite this paper: Zakaria, N., Hashim, H., \& Yunus, M. Md. (2019). A Review of Affective Strategy and Social Strategy in Developing Students' Speaking Skills. Creative Education, 10, 3082-3090. https://doi.org/10.4236/ce.2019.1012232

Received: October 16, 2019

Accepted: November 26, 2019

Published: November 29, 2019

Copyright $\odot 2019$ by author(s) and Scientific Research Publishing Inc. This work is licensed under the Creative Commons Attribution International License (CC BY 4.0).

http://creativecommons.org/licenses/by/4.0/

\section{c) (i) Open Access}

\begin{abstract}
Speaking skill is one of the skills highlighted in language learning. Despite of that, it is considered as the most difficult skill to be mastered compared to other language skills such as listening, reading or writing. Therefore, proper selection of the best language learning strategies will help the students to improve students' speaking skills either inside ESL classroom or outside the classroom. This paper reviews two main language learning strategies which are affective strategy and social strategy in developing students' speaking skills. This paper suggests that different approaches should be taken to improve language learning especially for speaking skills. Underpinned by the students' aspirations and the policy of Enhancing Malay Language and Strengthening English Language (MBMMBI), affective strategy and social strategy have been highlighted to enhance language learning. This paper suggests how affective strategy and social strategy can be applied to enhance students' speaking skills.
\end{abstract}

\section{Keywords}

Affective Strategy, Social Strategy, Students, Speaking Skills

\section{Introduction}

Speaking skill is one of the skills highlighted in language learning (Hashim, Yunus, \& Hashim, 2019). The skill is required as a mean of communication, to impart knowledge or information from one person to another. It is considered as the most difficult skills to be mastered compared to other language skills such as listening, reading or writing. In addition, speaking skills usually left behind as teachers and students mainly focus on the writing test rather than the other lan- 
guage skills. Thus, it leads to negligence in emphasizing oral language learning. It was supported by Hosni (2014), who stated that both teachers and students perceived speaking skill has less importance in which learning English is only for academic purposes, not for daily uses.

As a second language, English is considered as difficult to learn especially in terms of speaking skills (Hashim, Yunus, \& Hashim, 2018). The anxiety and problem of speaking a second language instead of the first language may derive from less exposure of the language in a learning environment and community, lack of vocabulary and lack of confidence (Hashim \& Isa, 2012). Navarro (2009) emphasized on the responsibility of the teachers to identify the problems encountered by the students to speak English, analyse the problems and try to solve the problems as to improve students' speaking skills. The problems faced by the students may relate to linguistic or non-linguistic such as the factors that come within the inner self. Low self-esteem can lead to the problem of adept to speaking skills. According to Heriansyah (2012), the competency of speaking skills among students is measured based on the abilities of the students to convey messages or information clearly to other person and the receivers could understand what they are trying to say.

A study by Ibrahim, Aziz, Zakaria, \& Yunus (2018) proposes a low achievement among Malaysian students in speaking skills though they have been or still learning at school for many years. Majority of the students prefer to speak in the first language as they are lack of vocabulary that leads to frustration and demotivation to learn the second language. The preferences of using their mother tongue in speaking will most likely contribute to the incompetence of the students to use English in the learning process. Moreover, teachers should provide support for the students to practise speaking and be creative in teaching speaking skills to the students.

The selection of language learning strategies by teachers is crucial in the education system (Yunus et al., 2018). Teachers should choose and select the most suitable strategies that suit to their students which are of mixed abilities (Yunus, Sulaiman \& Embi, 2013). Suitable learning strategies will enable students to master the language either verbally or in written forms (Hashim, Rubaai, \& Yunus, 2019). Speaking which is considered difficult to master undeniably needs lots of practices. Kusnierek (2015) mentioned the teaching of speaking skills is depended in classroom whereby students have been exposed to the language and practise speaking within the lesson. They have limited time to practise as most of the students prefer to speak their first language (L1) compared to the second language (L2) after school. Moreover, as mentioned by Torky (2006) most of the time, teachers monopolize the lesson by continuously talking and explaining things which demotivate the students to become an active speaker and being dominant in speaking lesson. By selecting the best language learning strategies for speaking skills, students will be encouraged and eager to speak in English. They would be able to improve their speaking skills without any fear of making mistakes. According to Mandasari \& Oktaviani (2018), students' motivation will 
be triggered to speak when they know their learning preferences. In addition, teachers will have the chance to expose the experience in speaking English to students to be used outside school as well.

Therefore, the proper selection of the best language learning strategies will help the students to improve students' speaking skills either inside ESL classroom or outside the classroom where the language is useful in a real-life situation. With a conducive learning environment, students will be motivated to learn and able to practise speaking among themselves and later use the language broader than expected as opposed to the use of language solely in academic purposes. Many researchers have a focus on the issue of students' speaking skills. In their researches, Chou (2004) and Parra (2010) came out with the significant impacts of using socio-affective strategies in language learning. Nevertheless, the selection of language learning strategies by teachers to develop primary school students' speaking skills should be highlighted. This paper reviews the use of affective strategy and social strategy to develop primary school students' speaking skills.

\section{English as a Second Language (ESL)}

Every child has the right to receive education. In the Malaysian context, children will go to the nursery, kindergarten or pre-school and later to a primary school before they go further to secondary school. Each step was taken for them to establish and highlight their potential academically. The students begin their journey in primary school at the age of 7 years old and end their primary schooling at 12 years old. They have 5 years of opportunities to learn English as a second language for those students who go to national schools and as a third language for those students who go to Tamil or Chinese vernacular schools. Eventually, the Ministry of Education (2013) has laid the Students' Aspiration in Malaysian Education Blueprint in which students are required to be bilingual. They have to be able to use the Malay language alongside the English language. This aimed to prepare the students to be able to face globalization internationally. It is significant for the students to have adequate input of the second language learned especially all the four language skills mainly listening, speaking, reading and writing. There are few programmes introduced to be implemented at schools as to encourage the use of English among students starting from the pre-school stage up to secondary level such as the Highly Immersive Programme (HIP) which is under the policy of Enhancing Malay Language and Strengthening English Language (MBMMBI).

Bojovic \& Antonijevic (2017) stressed on the motivation of the primary school students in learning. The author mentioned there are some limitations of the students to go beyond than expected. However, students may become proficient in mastering the language especially in developing their speaking skills as they mingle among other students and create interactions between students and other students as well as between teachers and students. Teaching speaking skills is not easy as what has been perceived by many people as it involves pronunciation, 
vocabularies and etcetera. Thus, teachers have to identify and ensure their teaching strategies suit to the level of the students to boost their interest in speaking activities particularly developing their speaking skills.

\section{Speaking Skills}

There are many definitions of speaking skills which differ from a researcher to another. Kusnierek (2015) highlighted in a study about the definition and the importance of speaking skill to convey messages and information to other persons. In addition, speaking will create social interaction in each society. Hence, students are required to acquire speaking skills in language acquisition. Torky (2006) mentioned about two types of speaking that are a monologue, the speaking activity within oneself and dialogue which occur between two persons or more than that. While monologue, the persons involved will most likely use their first language as they talk to their selves. On the other hand, when people interact and communicate in pairs or groups of people, they usually tend to speak in a language that they all can understand. It is crucial for the people to speak clearly as to let the listeners comprehend all the information conveyed as it is.

\section{Bandura's Social Learning Theory}

This study is based on Bandura theory whereby students will be reinforced and motivated to improve speaking skills by the two language strategies mainly affective strategy and social strategy. Bandura (1971) described learning can take place by observing and imitating others. In addition, the author stressed the importance of reinforcement in the learning process. Students' performance and language proficiency can be related to the personal factors of motivation which categorize under affective strategy and the environmental factors that comes under the social strategy. Both strategies contribute primarily in the process of enhancing students' speaking skills (Figure 1).

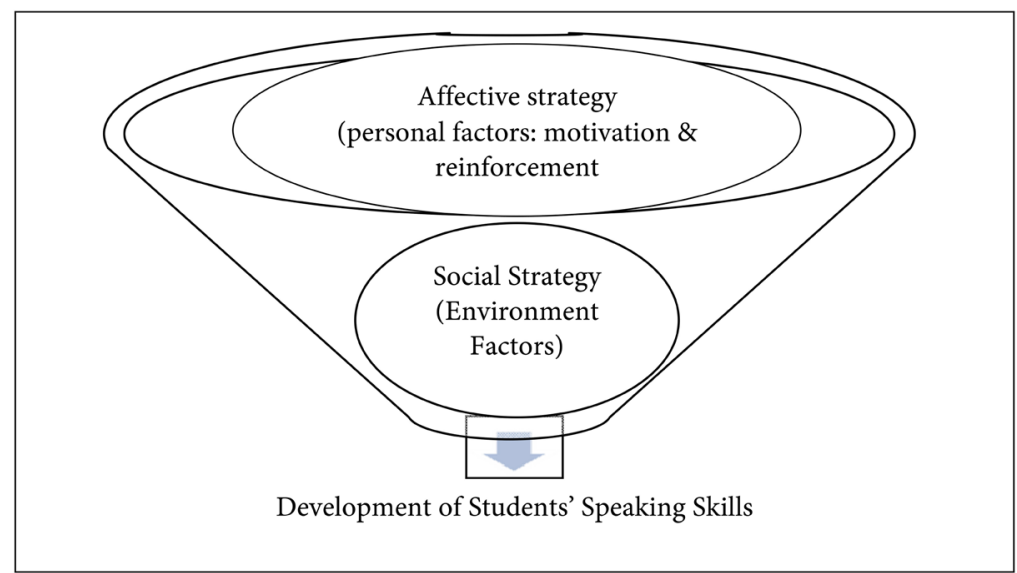

Figure 1. Conceptual framework of the language strategies to speaking skills. (Adapted from Bandura Social Learning Theory: 1971). 


\section{Affective Strategy}

Affective strategy is an indirect strategy of the language learning strategy (LLS). Mandasari \& Oktaviani (2018) indicated affective strategy is the most suitable strategy to motivate students in learning the second language. Students will be able to engage with their feelings and diminish the difficulties they face by motivating themselves. According to Lavasani \& Faryadres (2011), Oxford classified the strategy as one's control over their self-esteem as to create positive values in language learning. It is one of the characters of a good language learner whereby students can use positive factors to boost their language learning. According to Rossiter (2003), affective strategy helps students to cope with language learning whereby they will be able to relate the learning environment to their personal strength of learning. In other words, students will be able to solve any incoming problems while learning the language. It is an important fact that contributes to the enhancement of students' speaking skills. The positive environment creates a positive impact on students. Thus, obstacles in language learning are easy to be alleviated.

\section{Social Strategy}

Hardan (2013) revealed social strategy as one of the best strategies in language learning. Students can practise speaking with their peers. Some of the students are having a lack of confidence to speak in other languages than their native language. By practising speaking with their friends, students will be able to enhance their speaking skills as they are at the same level and age. In addition, Mandasari \& Oktaviani (2018) indicated students have opportunities to collaborate and become active language learners. They will become dominant in speaking as they have the freedom to use English without worrying about making mistakes in grammar and sentence structures. Rusdin (2018) stated communication and collaboration are two elements in 4'Cs beside creativity and critical thinking laid as a part of $21^{\text {st }}$-century learning. Students will be enabled to be active and practise speaking in English. Therefore, students' speaking skills will be enhanced besides listening, reading and writing skills.

\section{Discussion}

Speaking is a skill which has to be acquired by every student. They must get used to speak in English as a part of language learning. The obstacles in speaking have to be solved for the students to be able to master English language not only in written forms but also verbally. The anxious feeling to speak in English need to be overcome by both teachers and students. Both groups play vital roles to enable them to teach the skill and get the students to be engaged to practise speaking. Galti (2016) indicated the need of motivation among students to learn and to master speaking skills. Affective strategy is seen as the best strategy that can encourage students to speak without fear of making mistakes of grammar, pronunciation, errors in vocabulary or lack of fluency. The primary school students 
are the best target to start the use of affective strategy as they are at the fragile stage of learning and also capable of learning new knowledge or language easily compared to the adult learners. In addition, teachers have to persistently assist the students to speak in English.

Suliman, Mohd Nor, \& Yunus (2017) proposed the same idea whereby teachers should facilitate the mixed ability students with suitable learning methods that could cater their needs as well as to stimulate their readiness to speak regardless of their speaking anxiety. Another study by Zaki, Yunus, \& Hashim (2017) advocated the importance of being creative in the process of teaching and learning to promote fun learning in speaking lesson. Thus, students shall not feel English as a threat whenever they want to express their ideas as they would be able to speak without fear of making grammatical mistakes. Speaking in English would take place explicitly when students are comfortable with the learning environment, created by the teachers.

In a study by Wijirahayu \& Dorand (2018), they found that good attitudes of the students contribute to the effectiveness of the use of affective strategy in language learning. Moreover, the use of affective strategy has shown a positive impact on the students in motivating them to speak. Many studies have been conducted and showed the effectiveness of affective strategy to improve speaking skills through many interesting activities such as music, fun learning and etcetera. However, no study shows the affection of the students in speaking by appreciating their positive progress in speaking skills. Hence, students should be exposed to practise self-reward to acknowledge their performance in speaking skills. This will make the students to be motivated and try to do their best in speaking and able to lower their anxiety in speaking the second language. The emotional aspects of the primary school students need to be addressed in order for them to start speaking in English as the nurture of positive values should be emphasized as early age of children.

Another strategy that has been given a focal point in this study is the use of social strategy in developing speaking skills. The social strategy was mentioned by Henriquez, Von, Pena, \& Llanquileo (2017) as another language learning strategy which can support and enrich speaking skills among primary school students as they interact with each other. The advanced language learner will be able to help their friends to communicate in English. They will collaborate and support each other to complete the speaking task or group work together. Hence, there will be no students left behind without any assistance. In addition, social strategy leads to a conducive environment for the students to speak in English especially those students who are afraid of making mistakes when speaking in another language other than their mother tongue. They will feel safe as they become a part of the group and someone who is at their age can help them to overcome their anxiety. Working in pairs or groups of the same age or the same level usually have a positive impact to students' language learning as it is easier for them to give and share ideas, discuss the given topics and work on the task given by teachers. However, teachers should be ready to assist and find appro- 
priate tasks to encourage introvert students. They will more likely work alone. Thus, it is the teachers' responsibility to be aware of their students' level and students' preference in learning the second language especially in speaking.

\section{Implications and Conclusion}

In preparing students for the globalization of the modern era, English language skills primary speaking skills should be given extra focus. It begins at the early stage of education that is by focusing the primary school students as they can grasp the gist of the language easily based on teachers' teaching planning and strategies. Consequently, language learning strategies play vital roles in expanding speaking skills among young students. The use of affective strategy and social strategy to develop speaking skills can consolidate speaking in English and create a positive learning environment for primary school students. Nevertheless, few limitations need to be emphasized as it will recede the effectiveness of both language learning strategies to develop the speaking skills. Typically, the most important issues to be pointed out are: 1) the teachers' teaching strategies, 2) students' attitudes towards improving their speaking skills and 3) learning environment. These issues can be overcome and solved to ensure the development of students' speaking skills. First, teachers have to be equipped with adequate language skills, knowledge and pedagogical contents as to vary their teaching techniques or strategies. Second, students have to be motivated to boost their interest in learning English and raise their confidence level to speak in English. Lastly, the people in the society have to create conducive learning environment as it will affect the students' motivation and enthusiasm to develop the speaking skills.

The time has come for teachers to change their strategies to teach the students in the second language and focus all the important language skills without any negligence, especially in speaking skills. Speaking skills should not be left out though it is not being tested in the examination as it is important for students' communication skill. Hence, this study will provide a solution in bolstering teachers to choose and select the best language learning strategies and for the teachers to eliminate all possible obstacles in developing students' speaking skills. When students know the importance of speaking in English and relate it to the usage of the language internationally, they will be motivated to learn, practice speaking and finally develop their speaking skills. Further investigation towards the use of language learning strategies in developing speaking skills can be carried out for future analysis.

\section{Funding}

This research was supported by the grant from Universiti Kebangsaan Malaysia GG-2019-017, KRA-2018-044 and PP-FPEND-2019.

\section{Conflicts of Interest}

The authors declare no conflicts of interest regarding the publication of this paper. 


\section{References}

Bandura, A. (1971). Social Learning Theory. New York: General Learning Press. http://www.asecib.ase.ro/mps/Bandura_SocialLearningTheory.pdf

Bojovic, I., \& Antonijevic, R. (2017). Students' Motivation to Learn in Primary School. Open Journal for Psychological Research, 1, 11-20. https://doi.org/10.32591/coas.ojpr.0101.02011b

Chou, Y. L. (2004). Promoting Learners' Speaking Ability by Socio-Affective Strategies. The Internet TESL Journal, 10. http://iteslj.org/Articles/Chou-Socioaffective.html

Galti, A. M. (2016). Awareness of Students' on the Use of Affective Strategy and their Level of Speaking Anxiety. International Journal of Multidisciplinary Research and Development, 3, 319-322.

Hardan, A. A. (2013). Language Learning Strategies: A General Overview. Procedia-Social and Behavioral Sciences, 106, 1712-1726. https://doi.org/10.1016/j.sbspro.2013.12.194

Hashim, H. U., Yunus, M. M., \& Hashim, H. (2018). Language Learning Strategies Used by Adult Learners of Teaching English as a Second Language (TESL). TESOL International, 39.

Hashim, H. U., Yunus, M. M., \& Hashim, H. (2019). 3-Minutes Pitching with Flip Grid: An Antidote of Innovation for Speaking Anxiety. International Journal of Innovative Technology and Exploring Engineering, 8, 1798-1801.

Hashim, H., \& Isa, I. S. M. (2012). Students' Anxiety Level towards Speaking in English: Malaysia Polytechnic Experience. In 2012 IEEE Symposium on Business, Engineering and Industrial Applications (pp. 595-599). Bandung, Indonesia. https://doi.org/10.1109/ISBEIA.2012.6422957

Hashim, H., Rubaai, N., \& Yunus, M. M. (2019). Identifying English Language Learning Strategies Used by Polytechnic Students. Religación. Revista de Ciencias Sociales y Humanidades, 4.

Henriquez, T., Von, H., Pena, V., \& Llanquileo, E. A. (2017). The Effects of Memory and Social Strategies on Oral Production. Colombian Applied Linguistics Journal, 19, 209218. https://doi.org/10.14483/22487085.10535

Heriansyah, H. (2012). Speaking Problems Faced by the English Department Students of Syiah Kuala University. Lingua Didaktika, 6, 37-44. https://doi.org/10.24036/ld.v6i1.7398

Hosni, S. A. (2014). Speaking Difficulties Encountered by Young EFL Learners. International Journal on Studies in English Language and Literature, 2, 22-30.

Ibrahim, W. K. W., Aziz, N., Zakaria, N., \& Yunus, M. M. (2018). Enhancing Speaking Skill among Students in ESL Lesson through Instagram. The International Journal of Humanities \& Social Studies, 6, 126-132.

Kusnierek, A. (2015). Developing Students' Speaking Skills through Role-Play. World Scientific News, 7, 73-111.

Lavasani, M. G., \& Faryadres, F. (2011). Language Learning Strategies and Suggested Model in Adults Processes of Learning Second Language. Procedia-Social and Behavioral Sciences, 15, 191-197. https://doi.org/10.1016/j.sbspro.2011.03.072

Mandasari, B., \& Oktaviani, L. (2018). English Language Learning Strategies: An Exploratory Study of Management and Engineering Students. Premise: Journal of English Education and Applied Linguistics, 7, 61-78. https://doi.org/10.24127/pj.v7i2.1581

Ministry of Education Malaysia (2013). Malaysian Education Blueprint: 2013-2025 (Preschool to Post-Secondary Education). Kementerian Pendidikan Malaysia: Putrajaya. 
Navarro, B. R. (2009). Improving Speaking Skills. Encuentro: Revista De Investigacion E Innovacion En La Clase De Idiomas, 18, 86-90.

Parra, Y. J. F. (2010). Explicit Teaching of Socio-Affective Language Learning Strategies to Beginner EFL Students. Íkala, Revista De Lenguaje Y Cultura, 15, 145-169.

Rossiter, M. J. (2003). The Effects of Affective Strategy Training in the ESL Classroom. The Electronic Journal for English as a Second Language, 10. http://www.tesl-ej.org/wordpress/issues/volume7/ej26/ej26a2/

Rusdin, N. M. (2018). Teachers' Readiness in Implementing 21st Century Learning. International Journal of Academic Research in Business and Social Sciences, 8, 12931306. https://doi.org/10.6007/IJARBSS/v8-i4/4270

Suliman, A., Mohd Nor, M. Y., \& Yunus, M. M. (2017). Dual-Language Programme in Malaysian Secondary Schools: Glancing through the Students' Readiness and Unravelling the Unheard Voices. GEMA Online Journal of Language Studies, 17, 128-145. https://doi.org/10.17576/gema-2017-1704-09

Torky, S. A. E. F. (2006). The Effectiveness of a Task-Based Instruction Program in Developing the English Language Speaking Skills of Secondary Stage Students. Cairo: Ain Shams University.

Wijirahayu, S., \& Dorand, P. (2018). Affective Strategies, Attitudes, and a Model of Speaking Performance Development for Engineering Students. Journal of Physics: Conference Series, 948, Article ID: 012024.

https://doi.org/10.1088/1742-6596/948/1/012024

https://iopscience.iop.org/article/10.1088/1742-6596/948/1/012024/pdf

Zaki, M. H. S., Yunus, M. M., \& Hashim, H. (2017). The Use of Audio Visual Aids in Developing Pupils' Speaking Skills: Malaysian Context. Asian Social Science Journal, 4, 165-172. 